\title{
Trade Liberalisation, Competitiveness and the Real Exchange Rate (RER): An Analysis of Developments in South Africa during the 1990s
}

\section{Rangasamy}

International Economics Research Unit, South African Reserve Bank

\section{Harmse}

Investment and Trade Policy Centre, University of Pretoria

\section{ABSTRACT}

This paper tests whether tariff liberalisation has lead to increased competitiveness in the South African economy. The 46 sectors of the South African economy are classified as exportable, importable, importable and exportable and non-tradable. The impact of trade liberalisation on domestic prices for importables and exportables is then assessed by making use of real exchange rate calculations. It is concluded that while increased globalisation of production processes in South Africa may have improved the competitiveness of the tradable sector, tariff liberalisation played a minimal role in improving competitiveness in the manufacturing sector.

JEL F13, 31

\section{INTRODUCTION}

Extensive trade (tariff) liberalisation was implemented in South Africa during the 1990s. The primary motivation for this liberalisation policy was to improve competitiveness. A hypothesis that warrants further testing in the South African context is whether tariff liberalisation has led to increased competitiveness? This hypothesis informs the analysis in this paper. One way of assessing the effects of trade liberalisation is to consider its impact on the domestic prices for importables and exportables (Dijkstra, 1997: 8). This paper uses real exchange rate (RER) calculations based on the relative prices of exportables and importables to non-tradables to analyse the impact of tariff liberalisation on competitiveness during the 1990s.

Section Two gives an overview of some of the theoretical issues relating to the RER. Section Three provides a brief review of the tariff liberalisation policy of the 1990s. The penultimate section undertakes RER calculations and tests the 
above-mentioned hypothesis for South Africa during the 1990s. Finally, some conclusions are drawn in Section Five.

\section{SOME THEORETICAL CONSIDERATIONS: THE EFFECT OF TRADE LIBERALISATION ON THE RER}

The real exchange rate (RER) provides an indication of the competitiveness and profitability of producing tradable goods. However, there are different definitions of the real exchange rate, which has led to some confusion in the use of RERs in empirical analysis ${ }^{1}$. The purchasing power parity definition of the real exchange rate considers relative prices (domestic and international prices) multiplied by the exchange rate. This is given by:

$$
R E R_{1}=e \frac{P^{*}}{P}
$$

where e, $\mathrm{P}, \mathrm{P}^{*}$ refer to the exchange rate, domestic prices and foreign prices respectively. As Holden (1988: 1-2) points out, when consumer price indices (CPIs) are used as price measures, the RER captures the relative price of the baskets of consumption goods in the two countries. Similarly, when producer price indices (PPIs) or gross domestic product (GDP) deflators are used, the relative price of a basket of production goods is measured. In terms of equation (1) a country's competitiveness increases (decreases) if the relative price of its tradable goods decreases (increases). Changes in the RER in South Africa have attracted attention in economic literature (Holden, 1988; Kahn, 1998; Walters \& de Beer, 1999; Golub, 2000; Edwards \& Schoer, 2000). The afore-mentioned studies have considered different measures of the RER and have mostly argued there was an improvement in South Africa's competitiveness ${ }^{2}$. However, none of these studies have explicitly analysed the effects of trade liberalization on the RER competitiveness indicator.

The RER, measured as the ratio of the internal relative price of tradables $\left(\mathrm{P}_{t}\right)$ to the price of non-tradables $\left(P_{n}\right)$, is probably the most popular analytical definition of competitiveness (Edwards, 1992: 7). This definition emanated from the dependent economy model where the economy consisted of two sectors, namely the tradables and non-tradables sectors (Corden, 1985; Frenkel and Mussa, 1984; Frenkel and Razin, 1987) ${ }^{3}$. In this case the RER is given by: $R E R_{2}=\frac{P_{t}}{P_{n}}$

where $P_{t}$ and $P_{n}$ refer to the price of tradables and non-tradables respectively. 
An increase (decrease) in $R E R_{2}$ implies that the opportunity cost of producing tradables, measured in terms of foregone output of non-tradables has decreased (increased). This in effect means that the production of tradables is encouraged (discouraged). Stated differently, an increase (decrease) in $R E R_{2}$ depicts a decline (improvement) in competitiveness. Viewed in this way, RER changes reflect changes in the internal competitiveness of tradable goods vis-à-vis nontradable goods.

Aggregating exportables and importables into a single category implies that relative prices remain unchanged (Holden, 1988). However, the impact of trade liberalisation is not uniform across import and export prices. Liberalisation does not move the prices of exports and imports in the same direction, nor at the same pace. Thus, the use of a composite tradable price index in the calculation of the RER may not accurately indicate movements in competitiveness during periods of trade liberalization. Here, some of the important aspects in this regard are outlined, but readers are referred to Milner and McKay (1996) for a more elaborate exposition ${ }^{4}$.

The price of tradeables is a geometric average of the price of exportables $\left(P_{x}\right)$ and importables $\left(P_{m}\right)$, that is:

$$
P_{t}=P_{m}^{\beta} P_{x}^{(1-\beta)}
$$

where $\beta$ refers to the share of importables in tradables.

Substituting equation (3) into equation (2) and considering the proportionate change in the variables gives:

$$
R \hat{E} R_{2}=\beta \hat{P}_{m}+(1-\beta) \hat{P}_{x}-\hat{P}_{n}
$$

where $\hat{P}_{m}, \hat{P}_{x}$ and $\hat{P}_{n}$ refer to the proportionate change in the price of importables, exportables and non-tradables respectively.

Further, if it is assumed that the domestic price for exportables and importables is equal to the corresponding foreign prices multiplied by $e(1+t)$ and that foreign prices are constant $\left(\hat{P}^{*}=0\right)$ then, equation 4 can be expressed as:

$$
R \hat{E} R_{2}=\hat{e}+\beta d t_{m}+(1-\beta) d t_{x}-\hat{P}_{n}
$$

where $e=$ exchange rate; $t=$ trade measure; $d t_{i}=\left(1 \hat{+} t_{i}\right) ; i=x, m$ 
For simplicity a fixed exchange rate $(\hat{e}=0)$ and exogenously determined nontradeables prices $\left(\hat{P}_{n}=0\right)$ are assumed, then import liberalisation $\left(d t_{m}<0\right)$ would mean that in terms of equation 7 there is a real depreciation $\left(R E R_{2}<0\right)$. If the price of non-tradeables is endogenously determined - say a positive relationship between $P_{n}$ and the price of tradeables (i.e. $\hat{P}_{n}>0$ when $d t_{m}>0$ ) - then with import liberalisation $\left(d t_{m}<0\right) \quad R E R_{2}>0$ when $\left|\hat{P}_{n}\right|>\exists d t_{m}$ and $R E R_{2}<0$ when $\left|\hat{P}_{n}\right|<\exists d t_{m}$. Thus, the impact of trade liberalisation on $R E R_{2}$ is ambiguous and depends on the change in the price of non-tradables (Milner \& McKay, 1996: 78). The relationship between non-tradable and tradable goods prices has an important bearing on the definition of the RER. It is important to recognise that the income and substitution effects emanating from tariff liberalisation could also influence the price of non-tradables. To restore equilibrium in the economy, the proportionate change in the price of non-tradables $\left(\hat{P}_{n}\right)$ is given by:

$$
\hat{P}_{n}=w_{m} \hat{P}_{m}+w_{x} \hat{P}_{x}+u \hat{y}
$$

$$
\text { where } \begin{aligned}
w_{i} & =\frac{\eta_{n i}-\varepsilon_{n i}}{\varepsilon_{n n}-\eta_{n n}} \\
\mu & =\frac{\eta_{n}^{y}}{\varepsilon_{n n}-\eta_{n n}}
\end{aligned}
$$

$\eta_{n i}$ and $\varepsilon_{n i}$ are the elasticities of demand and supply for non-tradables with respect to the price of $i(i=m, x) . \quad \eta_{n}^{y}$ represents the income elasticity of demand for non-tradables.

The first two terms on the right hand side reflect the substitution effects while the last term captures the income effects ${ }^{5}$.

Assuming homogeneity of degree zero in prices implies that $w_{i}>0$ and the sum of $w_{i}$ is unity. Equation (6) can thus be rewritten as follows:

$$
\hat{P}_{n}=w_{m} \hat{P}_{m}+\left(1-w_{m}\right) \hat{P}_{x}+u \hat{y}
$$

Substituting (7) into (5) and for simplicity assuming no income effects $(\hat{y}=0)$ gives: 


$$
R \hat{E} R_{2}=\hat{e}+\beta d t_{m}+(1-\beta) d t_{x}-w_{m} \hat{P}_{m}+\left(w_{m}-1\right) \hat{P}_{x}
$$

This translates into:

$R \hat{E} R_{2}=\hat{e}+\left(\beta-w_{m}\right) d t_{m}+\left(w_{m}-\beta\right) d t_{x}$

with $\hat{P}_{m}=d t_{m} ; \hat{P}_{x}=d t_{x}$

Further, if it is assumed that an exchange rate adjustment is equivalent to a uniform tariff on imports $\left(e_{m}\right)$ and a subsidy on exports $\left(e_{x}\right)$ then the exchange rate effects could be represented as:

$\hat{e}=d t_{m} e_{m}+d t_{x} e_{x}$

substituting (10) into equation (9) gives:

$$
R \hat{E} R_{2}=\left(\beta-w_{m}\right)\left(d t_{m}+e_{m}\right)+\left(w_{m}-\beta\right)\left(d t_{x}+e_{x}\right)
$$

In summary the effects would be as follows:

- With no change in trade policy, the exchange rate effects are neutral.

- Trade liberalization $\left(d t_{m}<0 ; d t_{x}>0\right)$ accompanied by an exchange rate depreciation $\left(e_{x}>0 ; e_{m}>0\right)$ would cause the price of exportables to increase (since $d t_{x}>0 ; e_{x}>0$ ) but the movement in the price of importables is uncertain (since $d t_{m}<0 ; e_{m}>0$ ) i.e. import liberalization causes the prices of imports to decrease whilst the exchange rate depreciation causes importable prices to increase ${ }^{6}$. In addition, the substitution effects $\left(w_{m}\right)$ are important since they also influence the movement in the price of both exportables and importables.

There are a number of factors influencing the price of tradables and nontradables. The theoretical analysis presented above has considered four factors, namely, trade policy changes, exchange rate changes, the substitution and income effects. The analysis has shown that under certain conditions trade liberalization could have ambiguous effects on the price of importables. It is for this reason, that if the intention is to analyse the likely effects of trade liberalization, then the RER measure should distinguish between the exportables and importables sectors (Milner and McKay, 1996: 79). Defining the RER in terms of the price of exportables $\left(P_{x}\right)$ and importables $\left(P_{m}\right)$ and replacing $\left(P_{t}\right)$ with $\left(P_{x}\right)$ and $\left(P_{m}\right)$ in equation (2) gives two definitions of the RER namely ${ }^{7}$, 


$$
\begin{aligned}
& R E R_{2 a}=\frac{P_{x}}{P_{n}} \\
& R E R_{2 b}=\frac{P_{m}}{P_{n}}
\end{aligned}
$$

Since the primary concern here is the effects of tariff liberalisation during the 1990s, the effects of liberalisation on the two RER measures reflected in (12) and (13) need to be considered. With tariff liberalisation (and no change in the exchange rate), it can be expected that both $R \hat{E} R_{2 a}$ and $R \hat{E} R_{2 b}$ would depreciate (i.e. be $<0$ ); the depreciation in $R E R_{2 a}$ probably being less than that of $R E R_{2 b}{ }^{8}$. However, tariff liberalisation accompanied by a depreciation in the currency, would cause $R E R_{2 a}$ to depreciate. The likely effects of this on $R E R_{2 b}$ would now be ambiguous depending on whether tariff liberalisation exceeds the depreciation in the exchange rate and the likely income and substitution effects emanating from the implementation of tariff liberalisation. In the latter case, it is thus possible that, with large depreciations in the currency, import prices would not decrease with tariff liberalization in relative terms.

However, it is important to realize that separate relative price indices provide an indication of how macro-economic and other economic policies affect overall incentives in the economy (Edwards, 1997), and as such one should be careful not to assign the primary importance to trade policy effects without due consideration to other factors that could have precipitated the change in the $\mathrm{RER}^{9}$. The empirical work to date has not always given due consideration to this aspect.

Further, with imperfect competition, domestic prices may not change in the expected direction with trade liberalisation. A possible reason for this may be due to lower import prices at the border not being passed on consumers (Dijkstra, 1997: 8). This could result if there are a few importers dominating the market, or alternatively, if the retail network is dominated by a few sellers ${ }^{10}$. Another reason could be the prevalence of "pricing to market" behaviour on the part of foreign suppliers. In this case, profit margins are reduced to absorb the tariff so as to maintain market share. In such cases, tariff liberalisation may not necessarily lead to reduced import prices ${ }^{11}$. 


\section{A BRIEF REVIEW OF SOUTH AFRICA'S TARIFF LIBERALIZATION POLICY DURING THE $1990 \mathrm{~S}^{12}$}

By the beginning of the 1990s South Africa's official policy stance was one of export-oriented industrialisation. The General Export Incentive Scheme (GEIS) was introduced on 1 April 1990, with the objective of encouraging the production of value added exports. However, while export subsidies were used to reduce the anti export bias in the economy, the view that the path to export production should entail trade (and more specifically tariff) liberalisation began to gain ground. This is evident in the recommendations made by an official investigation into South Africa's tariff protection policy:

"Progress to greater export orientation, requires the responsible adjustment of the competitiveness of the existing industrial structure, which has been built up through import replacement, so as to enable it to deliver products at prices more in line with world prices. A generally accepted method of achieving this is to reduce tariffs and in addition, to follow a realistic exchange rate policy. The reduction of import tariffs is therefore an integral part of a process of progress towards export orientation" (IDC, 1990: i-ii) ${ }^{13}$.

This view was based on the evidence that South Africa: "had the most tariff lines (more than 13000), most tariff rates (200 ad valorem rates), the widest range of tariffs and the second highest level of dispersion (as measured by the coefficient of variation) among developing countries" (IMF, 2000: 54).

For policy makers in South Africa, "the lowering of tariffs will, however, serve first and foremost to strengthen the export orientation of South Africa's trade policy" (IDC, 1990: v). There was thus a firm belief that the tariff protection policies (of the previous decades) created an anti export bias and hence did not promote competitiveness and economic growth. At the beginning of 1990, the protection system consisted mainly of quantitative restrictions, customs duties and import surcharges. In addition, the protection policy was subject to frequent changes, biased against exports and fairly complex (Fallon and Pereira de Silva, 1994: 81$)^{14}$. The overall statutory tariff while not too high (approximately 28 per cent) by international standards, nevertheless had a wide dispersion. Within the manufacturing sector, consumer goods enjoyed the highest protection.

With the election of a democratic government in 1994, the economic policy bias towards exports as a major stimulant of economic growth was further entrenched. This is clearly borne out in the Growth, Employment and Redistribution (GEAR) strategy, which has since become a cornerstone of government policy. GEAR is aimed at "...strengthening the competitive 
capacity of the economy in the long term" (Government of South Africa, 1996: 7). Further; competitiveness in the tradable goods sector is to be achieved through: "a reduction in tariffs to contain input prices" (ibid., 1996: 4) ${ }^{15}$. Government policy is thus premised on the assumption that exports are vital for economic growth. Further, reduced input costs improve cost competitiveness, which in turn facilitates increased export production.

By the mid 1990s, it was clearly evident that the government was committed to abolishing GEIS, partly as a result of its incompatibility with GATT rules and partly because of a policy shift that entailed tariff liberalisation as a means of reducing the anti-export bias in the economy. The government's tariff liberalisation policy culminated in South Africa's offer to the GATT in 1994 and implemented in January 1995. In terms of the GATT offer, South Africa agreed to bind 98 per cent of all tariff lines and to cut tariffs by a third (Holden, 2001). The country also offered to convert all quantitative restrictions on agricultural imports to ad-valorem rates and to liberalise sensitive industries over an eightyear period (IMF, 2000: 54). The offer to GATT clearly displayed a commitment to opening up the economy to foreign competition ${ }^{16}$. In terms of the offer, industrial protection was to be substantially reduced over a five-year period from an average tariff of around 12 per cent in 1994 to approximately 5 per cent in 2001. The average import weighted tariff rates were to be reduced to well within the WTO bound rates; from 34 per cent to 17 per cent for consumption goods, from 8 per cent to 4 per cent for intermediate goods and from 11 per cent to 5 per cent for capital goods (TIPS, 2002: 11) ${ }^{17}$.

South Africa's commitment to liberalisation offer is borne out by an analysis of the applied rates over the latter half of the 1990s. The average import weighted tariffs since the GATT offer were significantly reduced from 28 per cent in 1990 to 10 per cent in 1998 (IMF, 2000: 55). For agricultural products the rate was lowered from 9.23 per cent (1996) to 1.4 per cent (2000) while for industrial products it was reduced from 11.4 (1996) per cent to 8.6 per cent (2000). The average for the economy as a whole has seen applied rates come down from 11.3 per cent in 1996 to 7.3 per cent in 2000 (TIPS, 2002: 14). Thus, the relevant question is whether the significant tariff liberalisation undertaken during the 1990s favourably impacted on competitiveness. This hypothesis will be tested for South Africa in the next section.

\section{TRADE LIBERALIZATION AND CHANGES IN THE RER IN SOUTH AFRICA DURING THE 1990S}

Section 2 highlighted the influence of trade liberalization on the prices of tradable goods. The first step in calculating RER measures of competitiveness 
is to develop separate price series for importables, exportables and non-tradable goods. This is the focus of the next section.

\subsection{Developing price measures for the tradable and non-tradable sectors}

In order to establish the disaggregated price series it is necessary to distinguish between the tradable and non-tradable sectors. While the distinction between tradable and non-tradable sectors is central to many economic theories and models, much of the empirical work has relied on crude estimates to distinguish between the sectors. One such approach relies on a-priori assumptions about sectors. For example, Goldstein and Officer (1979) suggest that since exports and imports dominate in the agriculture, mining and manufacturing sectors; these sectors could be regarded as tradable sectors. This distinction was used in a study for Australia (Shann, 1982 cited in Knight \& Johnson, 1997), Mauritius (Milner \& McKay, 1996) and South Africa (Holden, 1988). However, a major disadvantage of this classification is that it is performed at a fairly aggregate level and as such may lead to inaccuracies in measurement. This may be due to some sub-sectors or industries (for example, in manufacturing) being wrongly classified as tradable when they may not be engaging in trade or vice versa. In addition, this classification does not allow for a shift between the tradable and non-tradable sectors.

Knight and Johnson, (1997) suggest an industry based approach to distinguish between the tradable (exportables and importables) and non-tradable sectors. In this approach an industry is classified as exportable if it displays a significant degree of export orientation, importable if it is significantly involved in importsubstitution and otherwise non-tradable. For the classification of industries, the threshold values are important. Dwyer (1992), Balassa and Associates (1982) and Knight and Johnson (1997) suggest a threshold value of 10 per cent to distinguish between sectors. The distinction between sectors is done on the following basis:

- Exportable (E) sectors have an export orientation (exports as a ratio of domestic production) exceeding 10 per cent.

- Importable (I) sectors are those in which imports as a ratio of domestic demand exceeds 10 per cent.

- Non-tradable (NT) sectors are all other sectors in the economy.

- Tradable sectors include the exportable and importable sectors. 


\section{Table $1 \quad$ Classification of sectors}

\begin{tabular}{|c|c|c|c|c|c|c|c|c|c|c|c|c|c|}
\hline$[1]$ & $\begin{array}{l}\text { Lib. sect. } \\
{[2]}\end{array}$ & $\begin{array}{c}1990 \\
{[3]}\end{array}$ & $\begin{array}{c}1991 \\
{[4]}\end{array}$ & $\begin{array}{c}1992 \\
{[5]}\end{array}$ & $\begin{array}{c}1993 \\
{[6]}\end{array}$ & $\begin{array}{c}1994 \\
{[7]}\end{array}$ & $\begin{array}{c}1995 \\
{[8]}\end{array}$ & $\begin{array}{c}1996 \\
{[9]}\end{array}$ & $\begin{array}{l}1997 \\
{[10]}\end{array}$ & $\begin{array}{l}1998 \\
{[11]} \\
\end{array}$ & $\begin{array}{l}1999 \\
{[12]}\end{array}$ & $\begin{array}{c}2000 \\
{[14}\end{array}$ & $\begin{array}{l}2001 \\
{[15]}\end{array}$ \\
\hline Agr, forestry \& fishing & & E & E & E,I & E & $\bar{E}$ & $\bar{E}$ & $\bar{E}$ & $\bar{E}$ & $\bar{E}$ & $\overline{\mathrm{E}}$ & $\bar{E}$ & $\bar{E}$ \\
\hline Coal mining & & $\mathrm{E}$ & $\mathrm{E}$ & $\mathrm{E}$ & $\mathrm{E}$ & $\mathrm{E}$ & $\mathrm{E}$ & $\mathrm{E}$ & $\mathrm{E}$ & $\mathrm{E}$ & $\mathrm{E}$ & $\mathrm{E}$ & E,I \\
\hline $\begin{array}{l}\text { Gold and uranium } \\
\text { mining }\end{array}$ & & $\mathrm{E}$ & $\mathrm{E}$ & $\mathrm{E}$ & E & E & E & E & E & E & E & $\mathrm{E}$ & E \\
\hline Other mining & $\mathrm{L}$ & E,I & E,I & E,I & E,I & E,I & E,I & E,I & E,I & E,I & E,I & E,I & E,I \\
\hline Food & & NT & NT & NT & NT & NT & NT & $\mathrm{E}$ & $\mathrm{I}$ & E,I & $\mathrm{E}$ & E,I & E,I \\
\hline Beverages & & NT & NT & NT & NT & NT & NT & $\mathrm{E}$ & $\mathrm{E}$ & NT & $\mathrm{E}$ & $\mathrm{E}$ & $\mathrm{E}$ \\
\hline Tobacco & & NT & NT & NT & NT & NT & NT & NT & NT & $\mathrm{E}$ & $\mathrm{E}$ & $\mathrm{E}$ & $\mathrm{E}$ \\
\hline Textiles & & E,I & E,I & E,I & E,I & E,I & E,I & E,I & E,I & E,I & E,I & E,I & E,I \\
\hline Wearing apparel & $\mathrm{L}$ & NT & NT & NT & NT & NT & NT & NT & I & I & E,I & E,I & E,I \\
\hline Leather & & I & E,I & E,I & E,I & E,I & E,I & E,I & E,I & E,I & E,I & E,I & E,I \\
\hline Footwear & $\mathrm{L}$ & NT & NT & I & I & I & I & I & I & I & I & I & I \\
\hline Wood \& wood prod & $\mathrm{L}$ & NT & NT & NT & E,I & E,I & E,I & E,I & E,I & E,I & E,I & E,I & E,I \\
\hline Paper \& paper prod & $\mathrm{L}$ & E,I & E,I & E,I & E,I & E,I & E,I & E,I & E,I & E,I & E,I & E,I & E,I \\
\hline Print, pub \& recording & & I & $\mathrm{I}$ & I & $\mathrm{I}$ & I & $\mathrm{I}$ & $\mathrm{I}$ & $\mathrm{I}$ & I & $\mathrm{I}$ & $\mathrm{I}$ & I \\
\hline Coke and ref petrol & $\mathrm{L}$ & $\mathrm{E}$ & $\mathrm{E}$ & $\mathrm{E}$ & $\mathrm{E}$ & $\mathrm{E}$ & $\mathrm{E}$ & E,I & E,I & E,I & E,I & E,I & E,I \\
\hline Basic chemicals & $\mathrm{L}$ & E,I & E,I & E,I & E,I & E,I & E,I & E,I & E,I & E,I & E,I & E,I & E,I \\
\hline $\begin{array}{l}\text { Other chem \& man } \\
\text { fibres }\end{array}$ & $\mathrm{L}$ & I & I & I & I & I & I & I & I & I & I & I & I \\
\hline Rubber & & I & I & I & I & I & E,I & E,I & E,I & E,I & E,I & E,I & E,I \\
\hline Plastic prod & $\mathrm{L}$ & NT & NT & NT & NT & NT & NT & I & I & I & I & I & I \\
\hline Glass \& glass $\mathbf{p}$ & $\mathrm{L}$ & $\mathrm{I}$ & I & I & E,I & I & I & E,I & E,I & E,I & E,I & E,I & E,I \\
\hline Non metallic n & & NT & NT & NT & NT & $\mathrm{I}$ & $\mathrm{I}$ & I & $\mathrm{I}$ & I & E,I & $\mathrm{I}$ & E,I \\
\hline Basic iron \& steel & $\mathrm{L}$ & $\mathrm{E}$ & $\mathrm{E}$ & E,I & $\mathrm{E}$ & E,I & E,I & E,I & E,I & E,I & E,I & E,I & E,I \\
\hline Basic n & $\mathrm{L}$ & E,I & E,I & E,I & E,I & E,I & E,I & E,I & E,I & E,I & E,I & E,I & E,I \\
\hline Metal prod excl mach. & & NT & NT & NT & I & $\mathrm{I}$ & E,I & E,I & E,I & E,I & E,I & E,I & E,I \\
\hline Machinery \& e & $\mathrm{L}$ & $\mathrm{I}$ & $\mathrm{I}$ & E,I & E,I & E,I & E,I & E,I & E,I & E,I & E,I & E,I & E,I \\
\hline Electrical machinery & $\mathrm{L}$ & I & I & I & I & I & E,I & E,I & E,I & E,I & E,I & E,I & E,I \\
\hline TV radio and equip & $\mathrm{L}$ & $\mathrm{I}$ & $\mathrm{I}$ & $\mathrm{I}$ & $\mathrm{I}$ & $\mathrm{I}$ & E,I & E,I & E,I & E,I & E,I & E,I & E,I \\
\hline Professional \& scientific & $\mathrm{L}$ & E,I & E,I & E,I & E,I & E,I & E,I & E,I & E,I & E,I & E,I & E,I & E,I \\
\hline Motor vehicles parts & $\mathrm{L}$ & I & I & I & I & I & I & I & E,I & E,I & E,I & E,I & E,I \\
\hline Other transport & $\mathrm{L}$ & I & E,I & E,I & E,I & E,I & E,I & E,I & E,I & E,I & E,I & E,I & E,I \\
\hline Furniture & $\mathrm{L}$ & NT & NT & NT & NT & $\mathrm{E}$ & $E$ & $\mathrm{E}$ & $\mathrm{E}$ & E,I & E,I & E,I & E,I \\
\hline Other manufact. & $\mathrm{L}$ & E,I & E,I & E,I & E,I & E,I & E,I & E,I & E,I & E,I & E,I & E,I & E,I \\
\hline Electricity, gas \& & $\mathrm{L}$ & NT & NT & NT & NT & NT & NT & NT & NT & NT & NT & NT & NT \\
\hline Water supply & & NT & NT & NT & NT & NT & NT & NT & NT & NT & NT & NT & NT \\
\hline Building constr & & NT & NT & NT & NT & NT & NT & NT & NT & NT & NT & NT & NT \\
\hline Civil eng. \& other constr. & & NT & NT & NT & NT & NT & NT & NT & NT & NT & NT & NT & NT \\
\hline $\begin{array}{l}\text { Wholesale and retail } \\
\text { trade }\end{array}$ & & NT & NT & NT & NT & NT & NT & NT & NT & NT & NT & NT & NT \\
\hline $\begin{array}{l}\text { Catering \& accomm. } \\
\text { serv. }\end{array}$ & & E,I & E,I & $\mathrm{I}$ & $\mathrm{I}$ & E,I & E,I & E,I & E,I & E,I & E,I & E,I & $\mathrm{E}, \mathrm{I}$ \\
\hline Transport \& storage & & $\mathrm{E}$ & $\mathrm{E}$ & NT & NT & $\mathrm{E}$ & $\mathrm{E}$ & $\mathrm{E}$ & $\mathrm{E}$ & $\mathrm{E}$ & $\mathrm{E}$ & $\mathrm{E}$ & $\mathrm{E}$ \\
\hline Communication & & NT & NT & NT & NT & NT & NT & NT & NT & NT & NT & NT & NT \\
\hline Finance \& insurar & & NT & NT & NT & NT & NT & NT & NT & NT & NT & NT & NT & NT \\
\hline Business services & & NT & NT & NT & NT & NT & NT & NT & NT & NT & NT & NT & NT \\
\hline $\begin{array}{l}\text { Medical, dental and vet. } \\
\text { serv. }\end{array}$ & & NT & NT & NT & NT & NT & 11 & NT & NT & NT & NT & NT & NT \\
\hline $\begin{array}{l}\text { Excl medical, dental \& } \\
\text { vet. serv. }\end{array}$ & & NT & NT & NT & NT & NT & NT & NT & NT & NT & NT & NT & NT \\
\hline Other producers & & NT & NT & NT & NT & NT & NT & NT & NT & NT & NT & NT & NT \\
\hline General govt. services & & NT & NT & NT & NT & NT & NT & NT & NT & NT & NT & NT & NT \\
\hline
\end{tabular}

Source: Data from Tips, own calculations 
Table 1 (see previous page) classifies the 46 sectors of the South African economy into either exportable (E), importable (I), importable and exportable $(\mathrm{I}, \mathrm{E})$ or non-tradable $(\mathrm{NT})$. The dynamic nature of the classification procedure is clearly evident from the table as in the case of the food sector, which was classified as non-tradable up until 1995, exportable for 1996 and 1999 and importable for 1997 and both exportable and importable for 1998, 2000 and 2001. The number of non-tradable sectors has decreased from 22 (1990) to 12 (2001) during the period under analysis. Of interest is that the number of sectors that are classified as importable and exportable (I,E) has increased from 8 in 1990 to 25 in 1991. This indicates that a larger number of sectors have been subject to increased competition in both the domestic and international markets. The question at this point is, what has been the role of tariff liberalisation on the competitiveness of these sectors?

Table 1 (column 2) also reflects those sectors that became more liberalised during the 1990s. This classification is based on the relative change in the average effective rate of protection (ERP) measures between the period 1988-93 and 1994-98. A minimum 10 per cent reduction qualifies the sector for classification as liberalised. The ERP measures used in the classification of the sectors are contained in Table 2 (see later page).

Using this industry classification, the price series at the disaggregated sector level are established. Trade liberalisation measures are meant to influence the prices received by domestic producers for their output. Table 3 reflects the respective price series.

The price of importables $\left(P_{m}\right)$ is the weighted sum of the GDP deflators for the importable sectors ${ }^{18}$. Similarly the price of non-tradables is given by the weighted sum of GDP deflators for the non-tradable sectors. Three different calculations are undertaken for the price of exportables. $P_{x}^{1}$ is an export weighted sum of GDP deflators for the exportable sectors ${ }^{19} . P_{x}^{2}$ is an exportweighted sum of the price of exports of the respective industries ${ }^{20} . P_{x}^{3}$ is the export price series calculated by the South African Reserve Bank (SARB) ${ }^{21}$. It is interesting to note that there is very little difference between $P_{x}^{1}$ and $P_{x}^{2}$ which implies that there is very little difference between the prices charged for domestic goods and similar goods that are exported. However, the price series of the SARB $\left(P_{x}^{3}\right)$ shows a significant upward divergence after 1995. This may be primarily due to the SARB index being dominated by resource intensive commodities and as such the depreciation of the currency, coupled with the increases in commodity prices during the latter part of the 1990s, may have biased the price index upwards ${ }^{22} . P_{t}$ is a weighted sum of $P_{x}^{2}$ and $P_{m}{ }^{23}$. 
Table 2 Effective rate of protection for sectors of the South African economy

\begin{tabular}{|c|c|c|c|c|c|c|c|c|c|c|c|c|c|}
\hline Sector & ERP88 & ERP89 & ERP90 & ERP91 & ERP92 & ERP93 & ERP94 & ERP95 & ERP96 & ERP97 & ERP98 & $\begin{array}{c}\text { ERP88- } \\
93 \\
\end{array}$ & $\begin{array}{c}\text { EPR94- } \\
98 \\
\end{array}$ \\
\hline Agr, Forestry \& fishing & 0.04 & 0.04 & 0.05 & 0.06 & 0.06 & 0.06 & 0.06 & 0.05 & 0.07 & 0.06 & 0.08 & 0.052 & 0.064 \\
\hline Coal mining & -0.01 & -0.01 & -0.01 & -0.01 & -0.01 & -0.01 & -0.01 & -0.01 & -0.01 & -0.01 & -0.01 & -0.010 & -0.010 \\
\hline $\begin{array}{l}\text { Gold \& uranium } \\
\text { mining }\end{array}$ & 0.00 & 0.00 & 0.00 & 0.00 & 0.00 & 0.00 & 0.00 & 0.00 & 0.00 & 0.04 & 0.02 & 0.000 & 0.012 \\
\hline Other mining & -0.08 & -0.04 & -0.04 & -0.07 & -0.07 & -0.07 & -0.08 & -0.05 & -0.06 & -0.04 & -0.04 & -0.062 & -0.054 \\
\hline Food & -0.01 & -0.01 & 0.02 & 0.04 & 0.07 & 0.05 & 0.08 & 0.07 & 0.05 & 0.06 & 0.06 & 0.027 & 0.064 \\
\hline Beverages & 0.03 & 0.00 & 0.00 & 0.01 & 0.00 & 0.01 & 0.01 & 0.01 & 0.01 & 0.02 & 0.01 & 0.008 & 0.012 \\
\hline Tobacco & 0.02 & 0.02 & 0.06 & 0.02 & 0.03 & 0.06 & 0.07 & 0.22 & 0.07 & 0.22 & 0.04 & 0.035 & 0.124 \\
\hline Textiles & 0.15 & 0.14 & 0.11 & 0.10 & 0.07 & -0.01 & 0.03 & 0.08 & 0.17 & 0.17 & 0.23 & 0.093 & 0.136 \\
\hline Wearing apparel & 0.15 & 0.19 & 0.15 & 0.09 & 0.08 & 0.03 & 0.06 & 0.07 & 0.07 & 0.11 & 0.11 & 0.115 & 0.084 \\
\hline Leather & 0.22 & 0.20 & 0.20 & 0.21 & 0.20 & 0.21 & 0.20 & 0.17 & 0.22 & 0.24 & 0.26 & 0.207 & 0.218 \\
\hline Footwear & 0.33 & 0.26 & 0.24 & 0.31 & 0.33 & 0.33 & 0.34 & 0.21 & 0.23 & 0.23 & 0.21 & 0.300 & 0.244 \\
\hline Wood \& wood prod & 0.03 & 0.02 & 0.03 & 0.02 & -0.01 & 0.02 & 0.02 & 0.00 & 0.01 & 0.02 & 0.02 & 0.018 & 0.014 \\
\hline Paper \& paper prod & 1.24 & 1.14 & 1.00 & 1.15 & 1.14 & 1.20 & 0.87 & 0.49 & 0.62 & 0.54 & 0.56 & 1.145 & 0.616 \\
\hline Print, pub \&recording & 0.14 & 0.10 & 0.11 & 0.15 & 0.14 & 0.14 & 0.14 & 0.10 & 0.14 & 0.14 & 0.15 & 0.130 & 0.134 \\
\hline Coke \& ref petrol & -0.01 & -0.02 & -0.01 & -0.02 & -0.01 & -0.01 & 0.00 & -0.01 & -0.03 & -0.01 & -0.01 & -0.013 & -0.012 \\
\hline Basic chemicals & 0.10 & 0.06 & 0.06 & 0.04 & 0.04 & 0.05 & 0.03 & 0.03 & 0.03 & 0.02 & 0.03 & 0.058 & 0.028 \\
\hline $\begin{array}{l}\text { Other chem \& man } \\
\text { fibres }\end{array}$ & 0.05 & 0.04 & 0.04 & 0.05 & 0.03 & 0.03 & 0.03 & 0.02 & 0.08 & 0.03 & 0.01 & 0.040 & 0.034 \\
\hline Rubber & 0.17 & 0.18 & 0.18 & 0.17 & 0.16 & 0.16 & 0.16 & 0.13 & 0.16 & 0.19 & 0.18 & 0.170 & 0.164 \\
\hline Plastic prod & 0.17 & 0.15 & 0.15 & 0.34 & 0.15 & 0.16 & 0.16 & 0.10 & 0.12 & 0.10 & 0.11 & 0.187 & 0.118 \\
\hline Glass \& glass prod. & 1.25 & 1.14 & 0.88 & 0.86 & 0.86 & 0.93 & 0.78 & 0.54 & 0.46 & 0.47 & 0.57 & 0.987 & 0.564 \\
\hline Non metallic minerals & 0.01 & 0.00 & 0.01 & 0.01 & 0.01 & 0.01 & 0.01 & 0.00 & 0.01 & 0.01 & 0.01 & 0.008 & 0.008 \\
\hline
\end{tabular}


Table 2 continued

\begin{tabular}{|c|c|c|c|c|c|c|c|c|c|c|c|c|c|}
\hline Sector & ERP88 & ERP89 & ERP90 & ERP91 & ERP92 & ERP93 & ERP94 & ERP95 & ERP96 & ERP97 & ERP98 & \begin{tabular}{|c|} 
ERP88- \\
93 \\
\end{tabular} & \begin{tabular}{|c||} 
EPR94- \\
98 \\
\end{tabular} \\
\hline Basic iron \&steel & 0.21 & 0.20 & 0.23 & 0.22 & 0.19 & 0.21 & 0.21 & 0.13 & 0.15 & 0.17 & 0.16 & 0.210 & 0.164 \\
\hline Basic non ferrous met & 0.06 & 0.07 & 0.08 & 0.07 & 0.05 & 0.05 & 0.07 & 0.05 & 0.06 & 0.02 & 0.02 & 0.063 & 0.044 \\
\hline Metal prod excl mach. & 0.01 & 0.02 & 0.02 & 0.00 & 0.00 & 0.01 & 0.01 & 0.01 & 0.01 & 0.01 & 0.01 & 0.010 & 0.010 \\
\hline Machinery \& equip & 0.00 & -0.01 & 0.00 & 0.00 & 0.00 & 0.00 & 0.00 & 0.00 & 0.00 & 0.00 & 0.00 & -0.002 & 0.000 \\
\hline Electrical machinery & 0.05 & 0.04 & 0.04 & 0.04 & 0.04 & 0.04 & 0.03 & 0.02 & 0.04 & 0.03 & 0.03 & 0.042 & 0.030 \\
\hline TV radio \& equip & 0.11 & 0.11 & 0.12 & 0.11 & 0.12 & 0.12 & 0.09 & 0.06 & 0.03 & 0.03 & 0.02 & 0.115 & 0.046 \\
\hline Profess. \&scientific & 0.11 & 0.10 & 0.10 & 0.10 & 0.09 & 0.09 & 0.11 & 0.06 & 0.07 & 0.08 & 0.10 & 0.098 & 0.084 \\
\hline Motor vehicles parts & 0.08 & 0.07 & 0.06 & 0.07 & 0.05 & 0.05 & 0.03 & 0.03 & 0.04 & 0.04 & 0.02 & 0.063 & 0.032 \\
\hline Other transport & 0.01 & 0.00 & 0.01 & 0.01 & 0.01 & 0.01 & 0.00 & 0.00 & 0.01 & 0.00 & 0.00 & 0.008 & 0.002 \\
\hline Furniture & 0.17 & 0.07 & 0.08 & 0.11 & 0.08 & 0.04 & 0.01 & 0.03 & 0.05 & 0.06 & 0.04 & 0.092 & 0.038 \\
\hline Other industries & 0.05 & 0.04 & 0.05 & 0.05 & 0.04 & 0.04 & 0.03 & 0.02 & 0.02 & 0.00 & 0.00 & 0.045 & 0.014 \\
\hline Elect gas and steam & 0.07 & 0.07 & 0.07 & 0.07 & 0.07 & 0.07 & 0.07 & 0.05 & 0.07 & 0.06 & 0.06 & 0.070 & 0.062 \\
\hline Building const. & -0.01 & 0.00 & 0.00 & -0.01 & -0.01 & -0.01 & -0.01 & 0.00 & -0.01 & -0.01 & -0.01 & -0.007 & -0.008 \\
\hline Wholesale \& ret. trade & 0.00 & 0.00 & 0.00 & 0.00 & 0.00 & 0.00 & 0.00 & 0.00 & 0.00 & 0.00 & 0.00 & 0.000 & 0.000 \\
\hline Transport \&storage & 0.00 & 0.00 & 0.00 & 0.00 & 0.00 & 0.00 & 0.00 & 0.00 & 0.00 & 0.00 & 0.00 & 0.000 & 0.000 \\
\hline Finance and ins. & -0.19 & -0.18 & -0.20 & -0.20 & -0.20 & -0.20 & -0.20 & -0.15 & -0.22 & -0.17 & -0.18 & -0.195 & -0.184 \\
\hline $\begin{array}{l}\text { Med, dent, health \& } \\
\text { vet. }\end{array}$ & 0.00 & 0.00 & 0.00 & 0.00 & 0.00 & 0.00 & 0.00 & 0.00 & 0.00 & 0.00 & 0.00 & 0.000 & 0.000 \\
\hline
\end{tabular}

Source: Fedderke \& Vase, 2001, own calculations 


\section{Figure 1 Price of exportables, importables and non-tradables}

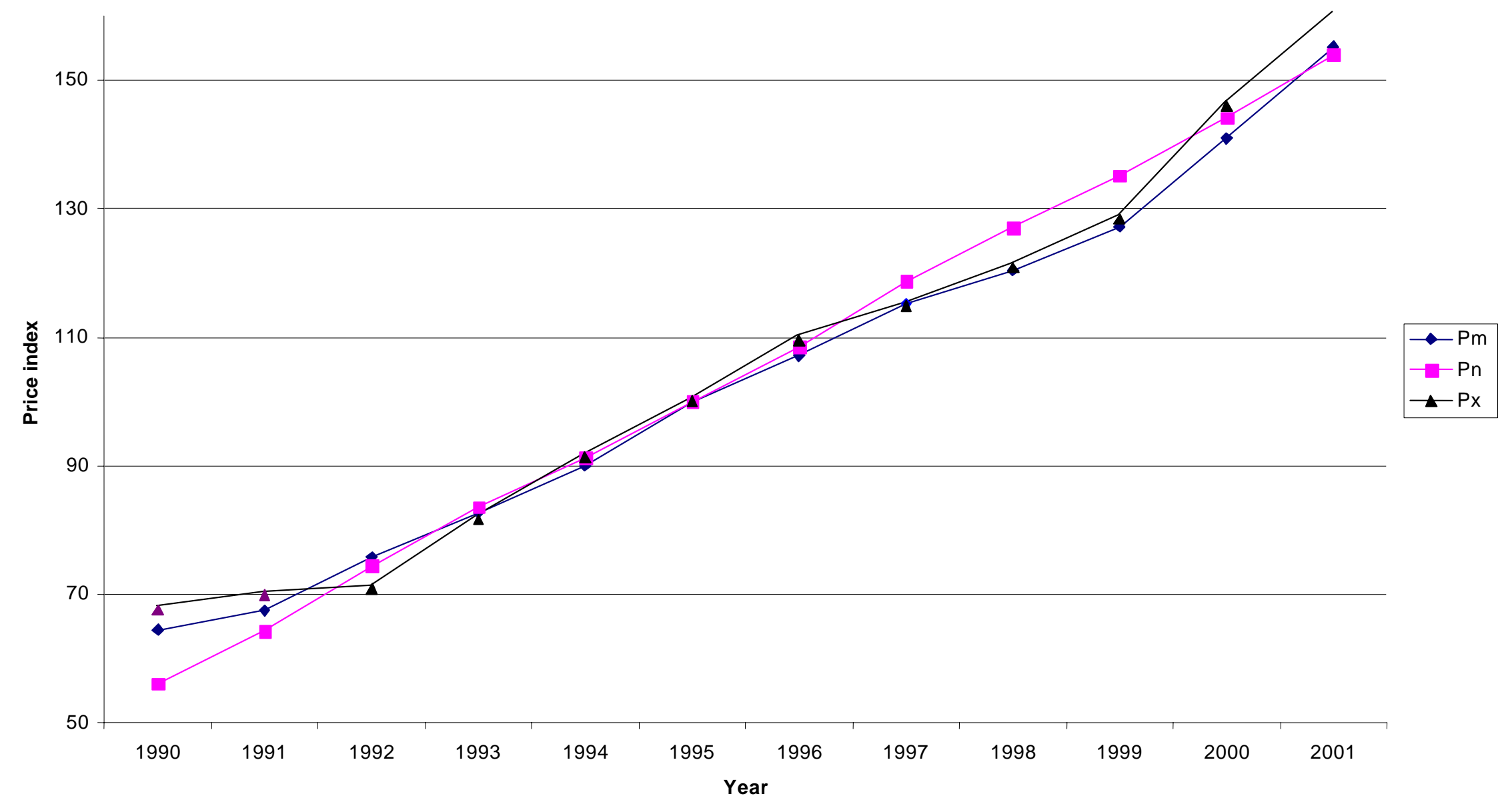


Figure 2 Growth rates of exportable, importable and non-tradable price

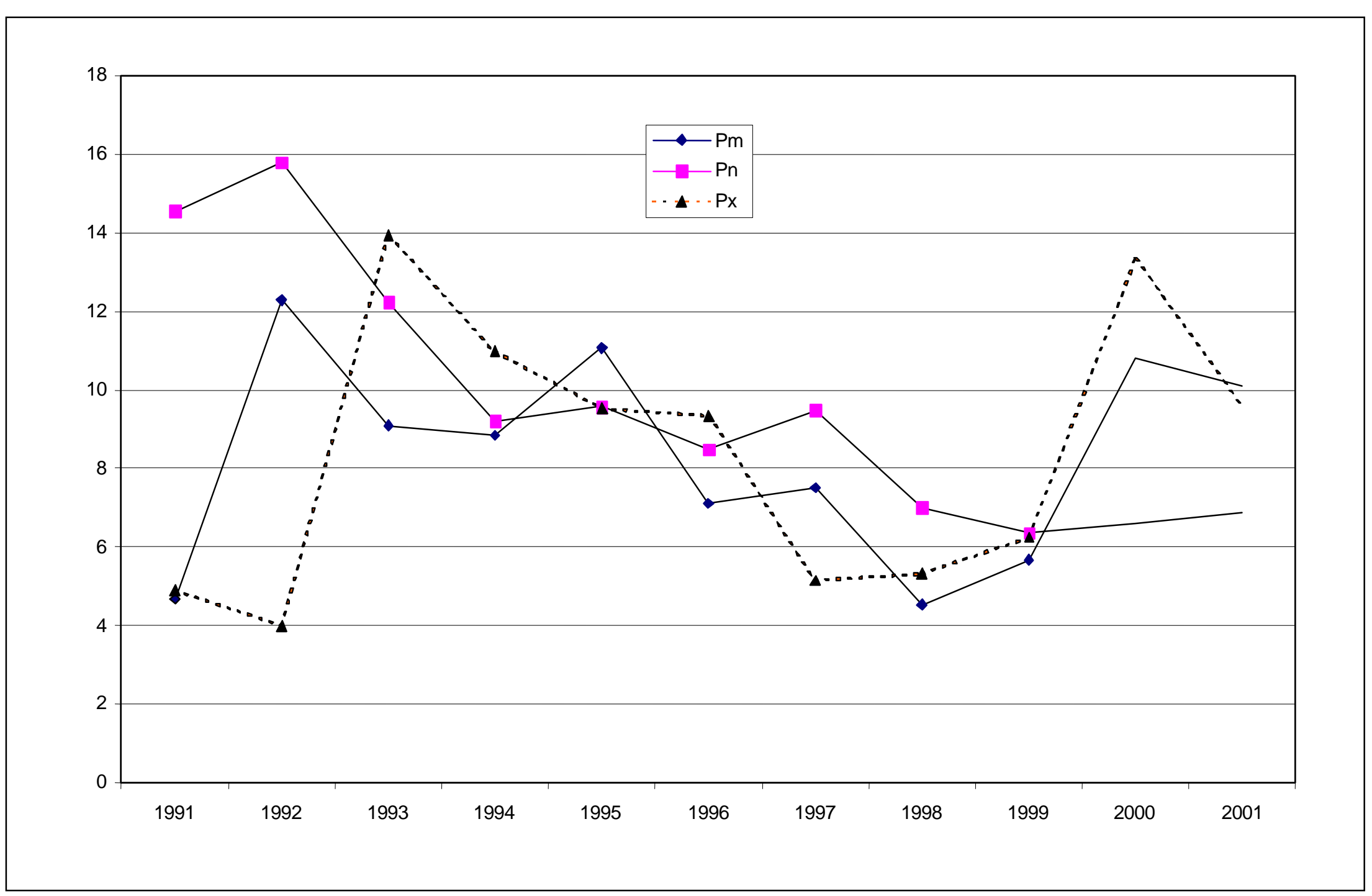


Figure 1 graphically depicts the price indexes for the importable, exportable and non-tradables sectors ${ }^{24}$. In general the trend is the same for all the price series. However, during the early 1990s, exportables and importables prices increased faster than those of non-tradables. Between 1996 and 2000, non-tradable prices increased faster than those of exportable and importable prices with a relative moderation in the price of tradables being particularly evident between 1995 and 1999.

The moderation in prices is analysed by considering the annual rate of increase in the price of exportables, importables and non-tradables sectors (Figure 2). This is informative as it gives an indication of the trend in the rate of price increases. The three price series have the same trend. Throughout the period under analysis there has been a continuous deceleration in the price of nontradables, to the extent that, by the end of the period under analysis, the annual rate of increase in prices was lower than that of the exportable and importable commodities. The price of importables shows a moderation in its rate of increase from 1995 to 1998 and the price of exportables from 1993 to 1997. However, the price increases of importables (since 1998) and exportables (since 1997) have accelerated quite rapidly. It is important to realise that the competitiveness of an industry does not depend on absolute but relative prices. This aspect is explored in more detail in the next section.

\subsection{Trade liberalisation and its effect on prices during the 1990s}

$P_{m}^{l}$ (in Table 3) reflects the price series for the importable sectors that were liberalised and $P_{m}^{n l}$ the importable sectors that were not liberalised ${ }^{25}$. The liberalised sectors are those reflected in column 2, Table 1. One advantage of distinguishing between the liberalising and non-liberalising sectors is that it provides an indication of the likely impact of trade liberalisation on prices. In other words, if all other effects (e.g. exchange rate changes, substitution and income effects, cost influences, etc.) are assumed to be uniform across the importables sector, then any divergence between $P_{m}^{l}$ and $P_{m}^{n l}$ would be due to trade liberalisation measures ${ }^{26} . P_{m}^{l}$ and $P_{m}^{\text {nl }}$ show very little divergence from each other implying that the price of importables that were liberalised increased at the same pace as those that were not liberalised. This suggests that the liberalisation implemented during the 1990s may not have had the intended (expected) effect of reducing the prices of importables.

Tsikata (1999: 10) argues that tariffs had a reduced impact on prices during the 1990s. Figure 2 provides some implicit support for this, in the sense that there is a moderation in increase in all tradable (exportables, importables and tradables) prices during the period of trade liberalisation (particularly between 1995 to 
1999). However, on closer examination, it should be noted that the moderation in prices began in the early 1990s - some time before the implementation of tariff reform in 1995. Thus the deceleration in prices suggests that there may be other factors (for example, the abolition of sanctions) that could have played a greater role in improving competitiveness than tariff liberalisation per se.

In addition, Tsikata's (ibid.) conclusions are drawn by comparing the local currency value of manufactures (MUVLC) and the domestic import price of manufactures (PPIM). MUVLC is proxied by "the product of the US dollarbased international manufactures unit value and the nominal exchange rate visà-vis the US dollar" (ibid.: 10) and this is taken to represent the expected rate of increase in domestic prices. A comparison (of MUVLC and PPIM) is taken to reveal whether import prices (PPIM) have in fact decreased faster than what would have been expected (MUVLC). However, some reservations can be expressed about the proxies used in the analysis. Firstly, the manner in which MUVLC is calculated does not give due recognition to the major differences between the structure of the US manufacturing sector vis-à-vis that of South Africa $^{27}$. Secondly, PPIM represents the price of imports and not necessarily importables; and in analysing the effects of liberalisation we are concerned with the impact of trade liberalisation on the price of importables ${ }^{28}$.

Table 3 Price series of exportables, importables, tradables and nontradables

\begin{tabular}{|r|r|r|r|r|r|r|r|r||}
\hline Year & $P_{m}$ & $P_{m}^{l}$ & $P_{m}^{n l}$ & $P_{n}$ & $P_{x}^{1}$ & $P_{x}^{2}$ & $P_{x}^{3}$ & $P_{t}$ \\
\hline 1990 & 65 & 65 & 62 & 56 & 68 & 66 & 69 & 65 \\
\hline 1991 & 68 & 70 & 70 & 64 & 70 & 69 & 72 & 69 \\
\hline 1992 & 76 & 75 & 78 & 74 & 71 & 72 & 77 & 74 \\
\hline 1993 & 83 & 83 & 83 & 84 & 82 & 82 & 83 & 82 \\
\hline 1994 & 90 & 90 & 90 & 91 & 91 & 91 & 93 & 91 \\
\hline 1995 & 100 & 100 & 100 & 100 & 100 & 100 & 100 & 100 \\
\hline 1996 & 107 & 107 & 106 & 108 & 110 & 109 & 108 & 108 \\
\hline 1997 & 115 & 115 & 116 & 119 & 115 & 115 & 116 & 115 \\
\hline 1998 & 120 & 120 & 122 & 127 & 121 & 121 & 129 & 121 \\
\hline 1999 & 127 & 128 & 128 & 135 & 128 & 129 & 138 & 128 \\
\hline 2000 & 141 & 145 & 132 & 144 & 146 & 146 & 157 & 143 \\
\hline 2001 & 155 & 155 & 155 & 154 & 160 & 160 & 183 & 158 \\
\hline
\end{tabular}

Source: Authors' calculations with data from Quantec

As mentioned earlier in the theoretical section, a measure of the internal competitiveness of a sector is obtained by considering the price indexes for the importables, exportables and tradable sectors relative to the price index for non- 
tradables (Dwyer, 1992: 451). An increase (decrease) in any of these relative prices represents a decline (improvement) in competitiveness. The price indices are reflected in Table 4.

Table 4 Relative prices of exportables, importables, tradables and non-tradables

\begin{tabular}{|l|c|c|c|c|c|}
\hline Year & $\frac{P_{t}}{P_{n}}$ & $\frac{P_{x}}{P_{n}}$ & $\frac{P_{m}}{P_{n}}$ & $\frac{P_{m}^{l}}{P_{n}}$ & $\frac{P_{m}^{n l}}{P_{n}}$ \\
\hline 1990 & 117 & 118 & 115 & 116 & 110 \\
\hline 1991 & 107 & 108 & 105 & 109 & 108 \\
\hline 1992 & 99 & 97 & 102 & 101 & 104 \\
\hline 1993 & 99 & 98 & 99 & 99 & 100 \\
\hline 1994 & 99 & 100 & 99 & 99 & 99 \\
\hline 1995 & 100 & 100 & 100 & 100 & 100 \\
\hline 1996 & 100 & 101 & 99 & 99 & 98 \\
\hline 1997 & 97 & 97 & 97 & 97 & 98 \\
\hline 1998 & 95 & 95 & 95 & 94 & 96 \\
\hline 1999 & 95 & 95 & 94 & 94 & 95 \\
\hline 2000 & 100 & 101 & 98 & 100 & 92 \\
\hline 2001 & 102 & 104 & 101 & 101 & 100 \\
\hline
\end{tabular}

Source: Table 3, authors' calculations

The RER measures recorded in Table 4 reveal some interesting characteristics of the tradable sectors. All indices depict a declining trend (improved competitiveness) for most of the period ${ }^{29}$. Once again it is evident that the improvement in competitiveness during the major part of the 1990s, started before the implementation of tariff reform. In addition, the fact that the competitiveness of the non-liberalised sectors $\left(\frac{P_{m}^{n l}}{P_{n}}\right)$ differs very little from the liberalised sectors $\left(\frac{P_{m}^{l}}{P_{n}}\right)$ also calls into question the extent to which tariff liberalisation may have increased competitiveness during the 1990s.

\section{CONCLUSIONS}

In this paper we have analysed the competitiveness of tradable sectors vis-à-vis non-tradable sectors using a variant of the conventional RER measure. While increased globalisation of production could have contributed to the improved competitiveness of the tradable sector, the evidence presented in this paper suggests that tariff liberalisation (which essentially began in 1995) may have 
played a minimal role in improving the level of competitiveness of South Africa's manufacturing sector. It could be the case that factors such as the abolition of sanctions, pricing to market behaviour on the part of foreign suppliers, domestic and international cost factors, etc. could have been more important determinants of competitiveness. These aspects warrant further empirical analysis.

\section{ENDNOTES}

1 See Edwards (1989) for a discussion of the ambiguities related to the different definitions of the RER

2 The evidence suggests that indicators based on real effective exchange rate calculations have overstated the extent of the improvement in South Africa's competitiveness. These studies have in the main emphasized the different theoretical and measurement issues pertaining to the calculation of the RER.

3 Tradables are classified as those goods whose prices are determined on the world market; they include both exportables and importables. Nontrabables on the other hand are classified as those goods whose prices are determined domestically.

$4 \quad$ Milner and Mackay (1996) provide an elegant theoretical justification for the use of disaggregated tradable (i.e. exportables and importables) price indices in the calculation of the RER. They use the RER calculations to date the liberalisation episode in Mauritius. However, in this paper we use the RER calculations to analyse the impact of trade liberalisation on competitiveness.

5 See Milner and McKay (1996) for a more elaborate exposition of these concepts.

6 This occurs even if import liberalization exceeds the depreciation in the currency (i.e. $d t_{m}+e_{m}<0$ ), $\operatorname{RER}_{2}>0$ when $\beta>w_{m}$

7 Following, Edwards (1992), the RER for the economy as a whole can be expressed as: RER $=\alpha R E R_{2 a}+(1-\alpha) R E R_{2 b}$ where $\alpha$ and $(1-\alpha)$ represent the respective trade weights.

8 The depreciation in $R E R_{2 a}$ depending on the share of imported inputs used in production. For simplicity the income and substitution effects are ignored.

9 An attempt is made to address this issue by distinguishing between the price movements in the price of liberalised and non-liberalised importables.

10 This was the case for food prices in Nicaragua (see Dijkstra ,1996). 
11 Therefore the analysis of the effects of pass-through effects of tariff changes to import prices is important to ascertain if the envisaged benefits (reduced import prices) are in fact realised.

12 See Bell, 1997 and Tips, 2002 for a more elaborate review of the protective measures during this period.

13 The minister of trade, industry and tourism commissioned the Industrial Development Corporation, in collaboration with the Board of Trade and Industry, to "investigate the efficacy of the existing tariff protection policy".

14 Complexity was due to a variety of different tariff rates and exemptions granted on a firm-by-firm basis rather than a product-by- product basis.

15 It is interesting to note that the objective of striving for international competitiveness is not meant to be isolated from social objectives. In fact one of the stated intentions of economic policy is "to support a competitive and more labour-intensive growth path" (GEAR, 1996: 7).

16 This section is mainly based on TIPS (2002).

17 The bound rates are 26 per cent, 4 per cent and 15 per cent for consumption, intermediate and capital goods respectively.

18 The Laspeyres price index formula was used which is given by $P=\sum w_{i t} \frac{P_{i t}}{P_{i 0}}$ where $w_{i t}$ reflects the share of industry $i$ contribution to the total value of output of the importables sector in time period t. $\mathrm{P}_{i t}$ is the price index of the commodities produced by industry $i$ in period $t$ and $\mathrm{P}_{\mathrm{i} 0}$ the price index of the commodities produced by industry $i$ in the base period. The price indices were proxied by the GDP industry deflators which were obtained from the TIPS standard industrial classification database.

19 The weight used in the calculation of the index is the share that the respective industries contribute to the value of exports of the exportable sectors.

20 The index was constructed from the export price series of the respective industries, which were obtained from the TIPS standard industrial classification database.

21 The export price series calculated by the SARB, is an extrapolation done from unit values of some of South Africa's major export commodities. The major difference between $P_{x}^{2}$ and $P_{x}^{3}$ is that the former is derived from the GDP deflators of all the exportable industries while the latter considers the export unit values of some of South Africa's major export commodities.

22 The nominal effective exchange rate depreciated by 35 per cent between 1990-95 and by 43 per cent between 1995-2001.

23 The weights are made up of exports and domestic demand for exportables and importables respectively. 
24 Export prices used in the graph are given by $P_{x}^{2}$ and import prices by $P_{m}$ in Table 3.

25 The weights used were the respective share of the industries to the value of output of the liberalised and non-liberalised importable sectors.

26 With the exception of 1992, 1997 and 1998, the price index for liberalised sectors was either the same (for most of the years) or even higher (as in 1996, 2000) than that for non-liberalised sectors.

27 The US manufacturing sector is composed of more technology intensive sectors.

28 As argued earlier on, it may the case that due to lack of competition between importers the benefits of lower import prices may not be passed on to consumers.

29 During 2000 and 2001 there was a relative decline in the competitiveness of the tradable sector.

\section{REFERENCES}

1 BALASSA \& ASSOCIATES (1982) Development Strategies in SemiIndustrial Economies, World Bank: Washington DC.

2 BELL, T. (1993) "Should South Africa further liberalise its foreign trade?" In Lipton, M. and Simpkins, C. (eds.) State and Market in PostApartheid South Africa, Witwatersrand University Press: Johannesburg.

3 BELL, T. (1997) "Trade policy" in Michie, J. and Padayachee, V (eds) The Political Economy of South Africa's Transition, Dryden Press: London.

4 CORDEN, M. (1985) Inflation, Exchange Rates and the World Economy, Third edition, Claredon Press: Oxford.

5 DIJKSTRA, A.G. (1997) "Trade liberalisation and industrial competitiveeness: the case of manufactured exports from Latin America", Paper presented at the 1997 conference of the Latin American Studies Association, Guadalajara, Mexico, 17-19 April.

6 DIJKSTRA, A.G. (1996) "The impact of structural adjustment programs on manufacturing: lessons from Nicaragua", in World Development, 24(3): 535-47.

7 DWYER, J. (1992) "The tradable non-tradable dichotomy: a practical approach", Australian Economic Papers, (December): 443-58.

8 EDWARDS, E. (1992) "Real exchange rates, competitiveness and macroeconomic adjustment in Nicaragua", Report prepared for the USAID under contract No. 524-0301-C-00-2036- 00. University of California: Los Angeles. 
9 EDWARDS, L. \& SCHOER, V. (2000) "The competitiveness of South African trade", University of Cape Town: Cape Town: www.commerce. uct.ac.za/economics/programs/postgrad.

10 EDWARDS, S. (1989) Real Exchange Rates, Devaluation and Adjustment: Exchange Rate Policy in Developing Countries, MIT Press: Cambridge, Massachusetts.

11 FALLON, P. \& PEREIRA DE SILVA, L. (1994) "South Africa: economic performance and policies", Informal Discussion Papers on Aspects of the SA Economy, No. 7, South Africa Department, World Bank: Washington.

12 FRENKEL, J.A. \& MUSSA, M. (1984) "Asset markets, exchange rates and the balance of payments: a reformulation of doctrine" in Jones, F. and Kenen, P (eds), Handbook of International Economics, North Holland: Amsterdam.

13 FRENKEL, J.A. \& RAZIN, A. (1987) Fiscal Policies and the World Economy, MIT Press: Cambridge, Massachusetts.

14 GOVERNMENT OF SOUTH AFRICA, (1996) Growth, Employment and Redistribution: a Macroeconomic Strategy, Ministry of Finance: Pretoria.

15 GOLDSTEIN, M. \& OFFICER, L. (1979) "New measures of prices and productivity for tradable and non-tradable goods", The Review of Income and Wealth, series 25(1): 413-27.

16 GOLDSTEIN, M. \& OFFICER, L. (1980) "Prices of tradable and nontradable goods in the demand for total imports", Review of Economics and Statistics, LXIII(2): 190-99.

17 GOLUB, S.S. (2000) "South Africa's international cost competitiveness", TIPS Working Paper no 14, TIPS: Johannesburg.

18 HOLDEN, M. (1988) "Definitions and calculations of real exchange rates: an application to South Africa", Occasional Paper no. 20, Economic Research Unit, Department of Economics, University of Natal: Durban.

19 HOLDEN, M. (2001) Trade Policy in a Liberalising Economy, mimeo, University of Natal: Durban.

20 INDUSTRIAL DEVELOPMENT CORPORATION (1990) Modification of the Application of Protection Policy, IDC: Sandton.

21 INTERNATIONAL MONETARY FUND (2000) "South Africa: selected issues", IMF Staff Country Report no. 00/42: 51-58, IMF: Washington.

22 KAHN, B. (1998) "Assessing South Africa's competitiveness: is the Reserve Bank's real exchange rate measure misleading?", Centre for Research and Finance in South Africa Quarterly Review, Centre for Research and Finance in South Africa, LSE: London.

23 KNIGHT, G. \& JOHNSON, L. (1997) "Tradables: developing output and price measures for Australia's tradable and non-tradable sectors", Working Paper no 97/1, Australian Bureau for Statistics: Canberra. 
24 MILNER, C. \& MCKAY, A. (1996) "Real exchange rate measures of trade liberalisation: some evidence for Mauritius", Journal of African Economies, 5(1): 69-91.

25 SHANN, E.W. (1986) "Australia's real exchange rate during the twentieth century: comment", in Nguyen, D. and Gregory, R. (eds), Exchange Rates and the Economy, Supplement to Economic Record: 79-91.

26 TRADE AND INDUSTRY POLICY STRATEGY (2002) The State of Trade Policy in South Africa, TIPS: Johannesburg.

27 TSIKATA, Y. (1999) "Liberalisation and trade performance in South Africa", Informal Discussion Papers on Aspects of the Economy of South Africa, Southern Africa Department, World Bank: Washington.

28 WALTERS, S \& DE BEER, B. (1999) "An indicator of South Africa's competitiveness", SARB Quarterly Bulletin, (September): 54-65. 